\title{
Maternal Near Miss Morbidity and Maternal Mortality in a Tertiary Referral Center in Turkey
}

\author{
Dilek UYGUR ${ }^{1}$, Yaprak ENGİN-ÜSTÜN' ${ }^{1}$, Özgür KARA¹, Kudret ERKENEKLİ ${ }^{1}$, Selcen YÜKSEL ${ }^{2}$, Salim ERKAYA $^{1}$ \\ Sema SANISOĞLU ${ }^{3}$, Nuri DANIŞMAN ${ }^{1}$, Aykan YÜCEL ${ }^{1}$
}

Ankara, Turkey

ABSTRACT

OBJECTIVE: The objective of the study is to present the maternal near miss and maternal mortality cases from a tertiary hospital and to evaluate the factors associated with the presence of maternal near miss.

STUDY DESIGN: We performed a retrospective study, including all women who fulfilled the WHO criteria for maternal near miss or death between June 2009 and June 2014 at a tertiary referral education hospital. This study was conducted to evaluate the risk factors' influence on near miss, multivariate logistic regression was used. Before setting logistic regression, univariate analyses were used to select candidate variables.

RESULTS: During the 5-year study, there were 82924 deliveries and 81673 live births. We identified 202 maternal near miss events and 11 maternal deaths. The maternal near miss ratio was 2.47 per 1.000 live births and the maternal mortality ratio was 13.46 per 100.000 live births. There were 213 women with a severe maternal outcome ratio (near miss + maternal death), with a ratio of 2.6 cases/1.000 live birth. Near miss events were associated with length of hospital stay $(p<0.001)$, hemoglobin level $(p=0.003)$.

CONCLUSION: By the help of the WHO near miss approach, we identified that near miss events were associated with length of hospital stay, hemoglobin level, cesarean section deliveries and parity.

Keywords: Near miss, Potentially life threatening, Maternal mortality, Maternal morbidity

Gynecol Obstet Reprod Med 2017;23(2):60-64

\section{Introduction}

Maternal mortality continues to be one of the most serious and intractable health problems. The deaths of more than 250.000 women during pregnancy and childbirth each year are largely preventable (1).

\footnotetext{
'Zekai Tahir Burak Women's Health Care Training and Research Hospital, Ankara

${ }^{2}$ Ylldirtm Beyazlt University Scool of Medicine Biostatistics Department, Ankara

${ }^{3}$ General Directorate of Mother and Child Health and Family Planning Ministry of Health of Turkey, Ankara

Address of Correspondence: Dilek Uygur

Zekai Tahir Burak Women's Health Care Training and Research Hospital, Ankara, Turkey

dilekuygur@gmail.com

Submitted for Publication: $\quad 16.12 .2016$

Accepted for Publication: $\quad 20.12 .2016$
}

\begin{tabular}{|c|c|}
\hline & Access this article online \\
\hline $\begin{array}{c}\text { Quick Response Code: } \\
\text { 口ats. }\end{array}$ & Website: www.gorm.com.tr \\
\cline { 2 - 3 } & DOI:10.201613/GORM.2016.652 \\
\hline
\end{tabular}

How to cite this article: Uygur D. Engin Üstün Y. Kara Ö. Erkenekli K. Yüksel S. Erkaya S et al. Maternal Near Miss Morbidity and Maternal Mortality in a Tertiary Referral Center in Turkey. Gynecol Obstet Reprod Med 2017;23(2):60-4
Maternal near miss defined as "a woman who nearly died but survived a complication that occurred during pregnancy, childbirth or within 42 days of termination of pregnancy" is receiving more attention and becoming an important indicator of the quality of obstetric care (2). The WHO technical working group recommends the maternal near-miss approach be considered in national plans for improving maternal health. Applying this approach should help to identify the health system shortfalls that countries need to address in order to reduce complications and fatal outcomes of pregnancy and childbirth (2).

The objective of this study was mainly to present the maternal near miss and maternal mortality cases from a tertiary referral education hospital. This is the first study from Turkey analyzing severe maternal morbidity using WHO near-miss criteria.

\section{Material and Method}

We performed a retrospective study, including all women who fulfilled the WHO criteria for maternal near miss or death between June 2009 and June 2014 at a tertiary referral education hospital. Our hospital is a tertiary health center and one of the largest public hospital in Turkey. The hospital handles about 17.000 deliveries annually, which include 5000 high 
risk pregnancies. Due to our hospital's feature of being a reference hospital, high risk pregnancies are frequent. The local ethics institutional board approved the study.

Maternal death was described as death during pregnancy or within 42 days' post-partum, regardless from the length or site of pregnancy, from any cause related to or aggravated by the pregnancy or its management, yet not from accidental or incidental causes (3). For identifying near-miss cases WHO criteria were used (Table 1) (4). Women with potentially lifethreatening conditions were identified according to criteria reported by WHO (Table 2) (4).

Two trained data collectors (KE, OK) assessed the medical records from patients' files. In order to identify women who had experienced a maternal near miss event or death; we as- sessed the files of all women who had had potentially life threatening conditions. Information on the demographic and health characteristics, pregnancy, delivery, and maternal and perinatal outcomes of individual women were recorded. We also included 2 patients with potentially life threating conditions after each maternal near miss case. Variables used for the definition of maternal near miss according to WHO criteria were retrospectively evaluated.

We calculated the maternal near miss ratio, defined as the number of maternal near miss events per 1,000 live births, and the maternal mortality ratio, defined as the number of maternal deaths per 100,000 live births. We also examined the association between maternal near miss and characteristics, namely, age, body mass index, time to start hysterectomy, length of hospital stay, hemoglobin level.

Table 1: The World healt organization maternal near miss criteria

\begin{tabular}{|c|c|c|}
\hline Clinical criteria & Laboratory-based criteria & Management-based criteria \\
\hline Shock & $\begin{array}{l}\text { Severe hypoperfusion (lactate }>5 \mathrm{mmol} / \mathrm{L} \\
\text { or }>45 \mathrm{mg} / \mathrm{dL} \text { ), }\end{array}$ & Use of continuous vasoactive drugs \\
\hline Cardiovascular arrest & Severe acidosis $(\mathrm{pH}<7.1)$ & Cardio-pulmonary resuscitation \\
\hline Acute cyanosis & $\begin{array}{l}\text { Severe hypoxemia }\left(\mathrm{O}_{2} \text { saturation }<90 \%\right. \\
\text { for } \geq 60 \text { minutes or } \mathrm{PAO}_{2} / \mathrm{FiO}_{2}<200\end{array}$ & $\begin{array}{l}\text { Intubation and ventilation not } \\
\text { related to anesthesia }\end{array}$ \\
\hline Gasping & $\begin{array}{l}\text { Severe acute azotemia (creatinine } \geq 300 \\
\mu \mathrm{mol} / \mathrm{mL} \text { or } \geq 3.5 \mathrm{mg} / \mathrm{dL} \text { ) }\end{array}$ & Dialysis for acute renal failure \\
\hline $\begin{array}{l}\text { Severe tachypnea } \\
\text { (respiratory rate }>40 \text { breaths per } \\
\text { minute) or severe bradypnea (respiratory } \\
\text { rate }<6 \text { breaths per minute) }\end{array}$ & $\begin{array}{l}\text { Severe acute thrombocytopenia } \\
<50000 \text { platelets } / \mathrm{mL} \text { ) }\end{array}$ & $\begin{array}{l}\text { Massive transfusion of blood or red cells } \\
\text { ( } \geq 5 \text { units) }\end{array}$ \\
\hline $\begin{array}{l}\text { Oliguria non responsive to fluids or } \\
\text { diuretics }\end{array}$ & $\begin{array}{l}\text { Severe acute hyperbilirubinemia } \\
\text { (bilirubin }>100 \mu \mathrm{mol} / / \text { or }>6.0 \mathrm{mg} / \mathrm{dL} \text { ) }\end{array}$ & $\begin{array}{l}\text { Uterine hemorrhage or infection leading to } \\
\text { hysterectomy }\end{array}$ \\
\hline \multicolumn{3}{|l|}{ Failure to form clots } \\
\hline \multicolumn{3}{|l|}{ Jaundice in the presence of preeclampsia } \\
\hline \multicolumn{3}{|l|}{$\begin{array}{l}\text { Any loss of consciousness not medically } \\
\text { induced, lasting }>12 \text { hours }\end{array}$} \\
\hline \multicolumn{3}{|l|}{ Stroke } \\
\hline \multicolumn{3}{|l|}{ Uncontrollable fit/status epilepticus } \\
\hline Total paralysis & & \\
\hline
\end{tabular}

Table 2: Potentially life-threatening conditions

\begin{tabular}{|l|l|}
\hline Women with severe complications & Women undergoing critical interventions \\
\hline Severe postpartum haemorrhage & Use of blood products \\
Severe pre-eclampsia & Interventional radiology \\
Eclampsia & Laparotomy \\
Sepsis or severe systemic infection & Admission to intensive care unit \\
Ruptured uterus & \\
Other complications associated with severe maternal outcome & \\
\hline
\end{tabular}




\section{Statistics}

To evaluate the risk factors', influence on near miss, multivariate logistic regression was used. Before setting logistic regression, univariate analyses were used to select candidate variables. Variables that have $\mathrm{p}$ values lower than 0.25 were taken as candidate variables for logistic regression. Poliserial correlation coefficient was used to define the correlation between near miss criteria and continuous variables. Type-I error rate was taken as $\alpha=0.05$ for statistically significance. SPSS 22.0 and $\mathrm{R}$ software was used for statistical analyses.

\section{Results}

In the 5-year study period, there were 82.924 deliveries and 81.673 live births. We identified 404 women with potentially life-threatening conditions, 202 maternal near miss events and 11 maternal deaths. The maternal near miss ratio was 2.47 per 1,000 live births $(95 \% \mathrm{CI})$ and the maternal mortality ratio was 13.46 per 100.000 live births $(95 \%$ CI). There were 213 women with a severe maternal outcome ratio (near miss + maternal death), with a ratio of 2.6 cases/1.000 live birth.

For the near miss events, the main criteria were: 114 management-based criteria, 46 clinical criteria and 107 laboratorybased criteria. The combination of these criteria (laboratory and management) was able to identify 17 cases of maternal near miss.

Table 3 summarizes the background characteristics of the study population. The mean age of the patients with maternal near miss events was $30.16 \pm 6.40$ compared to $32.79 \pm 5.62$ years for maternal mortality patients. Gestational age at delivery reached a median of $32.5 \pm 8.5$ weeks for the near miss events. The analyses revealed that the most frequent cause of maternal death was hypertensive disorders of pregnancy, followed by sepsis. For the cases of near miss, the most frequent cause was obstetric hemorrhage $(n=111,54.9 \%)$ followed by hypertensive disorders of pregnancy $(n=86,42.6 \%)$.

Near miss events were associated with length of hospital stay $(p<0.001)$, hemoglobin level $(p=0.003)$ (Table 4$)$. Women who had undergone 3 or more cesarean sections were at increased risk of maternal near miss $(\mathrm{OR}=15.1, \mathrm{p}=0.001$, $\% 95 \mathrm{CI}, 3.277-70.114)$. Also women with a parity of $1-3 \mathrm{com}-$ pared with 0 had a higher risk of being a near miss (OR=1.526, $\mathrm{p}=0.046$, \%95 CI, 1.008-2.310). Women with HELLP syndrome had an OR of 3.497 for occurrence of near miss compared with cases with placenta previa ( $p<0.001, \% 95$ CI: 2.131-5.741) (Table 5, 6).

Table 3: Underlying causes of potentially life-threatening conditions and life threatening conditions

\begin{tabular}{lccc}
\hline & $\begin{array}{c}\text { Women with potentially life- } \\
\text { threatening conditions } \\
(\mathrm{n}=404)\end{array}$ & $\begin{array}{c}\text { Maternal near- } \\
\text { miss cases } \\
(\mathrm{n}=202)\end{array}$ & $\begin{array}{c}\text { Maternal deaths } \\
(\mathrm{n}=11)^{*}\end{array}$ \\
\hline Maternal age $(\mathrm{y})$ & $29.35 \pm 4.77$ & $30.16 \pm 6.40$ & $32.79 \pm 5.62$ \\
Body mass index $\left(\mathrm{kg} / \mathrm{m}^{2}\right)$ & $29.04 \pm 3.86$ & $29.31 \pm 4.59$ & 0.079 \\
Parity & $1.2 \pm 1.14$ & $1.34 \pm 1.27$ & 0.586 \\
Gestational age $(\mathrm{wk})$ & $32.43 \pm 2.95$ & $32.5 \pm 8.5$ & $28.93 \pm 6.86$ \\
Obstetric hemorrhage, $\mathrm{n}(\%)$ & $270(66.8)$ & $111(54.9)$ & 0.178 \\
Hypertensive disorders, $\mathrm{n}(\%)$ & $134(33.1)$ & $86(42.6)$ & $7(64 \%)$ \\
Pregnancy-related infection, $\mathrm{n}(\%)$ & $0(0)$ & $5(2.5)$ & $2(18 \%)$ \\
Clinical criteria & - & 46 & 0.882 \\
Laboratory-based criteria & - & 114 & \\
Management-based criteria & - & 107 & \\
\hline
\end{tabular}

*The two remaining maternal deaths (18\%) occurred out of the hospital and the reasons were not clearly defined.

Table 4: Correlations between near miss criteria and continuous variables

\begin{tabular}{lcr}
\hline & Poliserial correlation coefficient & $p$ \\
\hline Age & -0.014 & 0.871 \\
Body mass index & -0.134 & 0.264 \\
Time to start hysterectomy & 0.424 & $<0.001$ \\
Length of hospital stay & 0.300 & $<0.001$ \\
Hemoglobin level & -0.240 & 0.003 \\
Platelet level & 0.218 & 0.005 \\
Number of units of blood products transfused & 0.528 & $<0.001$ \\
\hline
\end{tabular}


Table 5: Univariate analysis of demographic and obstetric related variables of maternal near-miss and potentially life-threatening conditions

\begin{tabular}{|c|c|c|c|}
\hline & $\begin{array}{l}\text { Maternal near-miss cases } \\
\qquad(n=202)\end{array}$ & $\begin{array}{l}\text { Women with potentially } \\
\text { life-threatening conditions } \\
\qquad(n=404)\end{array}$ & $p$ \\
\hline $\begin{array}{l}\text { Maternal age } \\
\leq 18 \text { y } \\
19-35 y \\
>35 y\end{array}$ & $\begin{array}{c}19 \\
127 \\
56\end{array}$ & $\begin{array}{c}22 \\
294 \\
88\end{array}$ & 0.030 \\
\hline $\begin{array}{l}\text { Parity } \\
0 \\
1-3 \\
>3\end{array}$ & $\begin{array}{c}68 \\
121 \\
13\end{array}$ & $\begin{array}{c}179 \\
209 \\
16\end{array}$ & 0.028 \\
\hline $\begin{array}{l}\text { Gestational week } \\
\geq 34 \mathrm{w} \\
<34 \mathrm{w}\end{array}$ & $\begin{array}{c}109 \\
90\end{array}$ & $\begin{array}{l}241 \\
163\end{array}$ & 0.254 \\
\hline $\begin{array}{l}\text { History of cesarear } \\
0 \\
1-2 \\
>2\end{array}$ & $\begin{array}{l}146 \\
45 \\
11\end{array}$ & $\begin{array}{c}309 \\
92 \\
3\end{array}$ & 0.001 \\
\hline $\begin{array}{l}\text { Mode of delivery } \\
\text { Vaginal delivery } \\
\text { Cesarean }\end{array}$ & $\begin{array}{c}36 \\
166\end{array}$ & $\begin{array}{c}94 \\
310\end{array}$ & 0.124 \\
\hline
\end{tabular}

Table 6: Logistic regression model for obstetric related variables of maternal near-miss and potentially life-threatening conditions

\begin{tabular}{|c|c|c|c|c|c|c|c|c|}
\hline & \multirow[t]{2}{*}{$B$} & \multirow[t]{2}{*}{ s.h. } & \multirow[t]{2}{*}{ Wald } & \multirow[t]{2}{*}{ s.d. } & \multirow[t]{2}{*}{$p$} & \multirow[t]{2}{*}{ OR } & \multicolumn{2}{|c|}{ OR $95 \% \mathrm{Cl}$} \\
\hline & & & & & & & $\begin{array}{c}\text { Lower } \\
\text { Limit }\end{array}$ & $\begin{array}{r}\text { Upper } \\
\text { Limit }\end{array}$ \\
\hline $1 \mathrm{CS}$ & .101 & .236 & .182 & 1 & .670 & 1.106 & .696 & 1.756 \\
\hline $2 \mathrm{CS}$ & 2.719 & .781 & 12.102 & 1 & .001 & 15.158 & 3.277 & 70.114 \\
\hline preeclampsia & -1.595 & .537 & 8.844 & 1 & .003 & .203 & .071 & .580 \\
\hline previa & .323 & .243 & 1.762 & 1 & .184 & 1.381 & .857 & 2.226 \\
\hline HELLP & 1.252 & .253 & 24.516 & 1 & .000 & 3.497 & 2.131 & 5.741 \\
\hline atony & .575 & .411 & 1.960 & 1 & .162 & 1.778 & .794 & 3.978 \\
\hline parity(1) & .422 & .212 & 3.983 & 1 & .046 & 1.526 & 1.008 & 2.310 \\
\hline parity(2) & .393 & .472 & .696 & 1 & .404 & 1.482 & .588 & 3.735 \\
\hline Constant & -1.410 & .240 & 34.590 & 1 & .000 & .244 & & \\
\hline
\end{tabular}

${ }^{*}$ The table consists of multivariate logistic regression test results and the variables are elaborated simultaneously

$\begin{array}{lllllll}B & \text { s.h. Wald } & \text { s.d. } & p & \text { OR } & \text { OR } & \text { CS }\end{array}$

\section{Discussion}

Because maternal deaths are infrequent, more frequent severe maternal morbidity becomes valuable sources of information to understand the set of preventable conditions that contributes to maternal death (5).

During the study period, 202 admissions of maternal near miss occurred at the unit, with 11 maternal deaths. Our study revealed that overall maternal near miss ratio was 2.47 per
1,000 live births and the maternal mortality ratio was 13.46 per 100,000 live births which was below the ratio of Turkey in 2007-2009 periods (19.7 per 100.000 live births) (6). As one of the largest public hospital in the country, the hospital handles about 17.000 deliveries annually. A recent systematic literature review on the prevalence of maternal near miss revealed a prevalence that ranged from $0.04 \%$ to $15 \%$ depending on the criteria used to define it (7). The management based criteria identified 114 of the 202 cases. 
In the present study, the analyses revealed that the most frequent cause of maternal death was hypertensive disorders of pregnancy, followed by sepsis. For the cases of near miss, the most frequent cause was obstetric hemorrhage followed by hypertensive disorders of pregnancy. Also women who had a long hospital stay and low hemoglobin level were found to be associated with the occurrence of a near miss. The results of the multivariate analysis indicated that a high cesarean section rate and parity were associated with the occurrence of maternal near miss. Litorp et al (8) also emphasized that the factors that remained significantly associated with an increased risk of severe maternal morbidity and near miss were a cesarean section in the current pregnancy.

In the study of Jabir et al (9), the maternal near-miss rate was 5.06 per 1,000 live births, while the overall maternal near miss: mortality ratio was 9:1. They found anemia (55\%) and previous cesarean section (45\%) to be the most common associated conditions with severe maternal morbidity. In a crosssectional study with a nested case-control component, Galvão et al (10) found the maternal near miss ratio to be 5.8 cases/1,000 live births. In the multivariate analysis, patient's status, previous caesarian, abortion and level of consciousness were reported as significant (10).

As a doctor, obstetrician and a perinatologist, our one of the most important goal is to decrease the maternal mortality and morbidity. In this context, worldwide organizations, regional and local societies have an important role for organization of the strategies and promoting the healthcare providers (11). The maternal near-miss approach is accepted as a new strategy for improving maternal health.

The fact that this is a retrospective study in which the data were collected from patient records constitute a limitation. But the findings from this study are important because the interventions associated with an improvement in one outcome may be associated with an improvement in the other.

Ensuring that more professionals are aware of and utilize the maternal near miss events, will result in more effective medical management of these cases.

\section{References}

1. Bustreo F, Say L, Koblinsky M, Pullum TW, Temmerman
M, Pablos-Méndez A. Ending preventable maternal deaths: the time is now. Lancet Glob Health 2013;1(4): e176-7.

2. Say L, Souza JP, Pattinson RC, WHO working group on Maternal Mortality and Morbidity classifications. Maternal near miss-towards a standard tool for monitoring quality of maternal health care. Best Pract Res Clin Obstet Gynaecol 2009;23(3):287-96.

3. World Health Organization. Manual of the international statistical classification of diseases, injuries and causes of death, $10^{\text {th }}$ revision, vol. 1. Geneva, Switzerland: World Health Organization;1993.

4. World Health Organization. (2011). Evaluating the quality of care for severe pregnancy complications: The WHO near-miss approach for maternal health. Geneva: WHO.

5. Pattinson RC, Buchmann E, Mantel G, Schoon M, Rees $\mathrm{H}$. Can enquiries into severe acute maternal morbidity act as a surrogate for maternal death enquiries? BJOG 2003 Oct;110(10):889-93.

6. Engin-Üstün Y, Çelen Ş, Özcan A, Sanisoğlu S, Karaahmetoğlu S, Gül R, et al. Maternal mortality from cardiac disease in Turkey: a population-based study. J Matern Fetal Neonatal Med 2012;25(11):2451-3.

7. Tunçalp O, Hindin MJ, Souza JP, Chou D, Say L. The prevalence of maternal near miss: a systematic review. BJOG 2012;119(6):653-61.

8. Litorp H, Kidanto HL, Rööst M, Abeid M, Nyström L, Essén B. Maternal near-miss and death and their association with caesarean section complications: a cross-sectional study at a university hospital and a regional hospital in Tanzania. BMC Pregnancy Childbirth 2014;14:244.

9. Jabir M, Abdul-Salam I, Suheil DM, Al-Hilli W, AbulHassan S, Al-Zuheiri A, et al. Maternal near miss and quality of maternal health care in Baghdad, Iraq. BMC Pregnancy Childbirth 2013;13:11.

10. Galvão LP, Alvim-Pereira F, de Mendonça CM, Menezes FE, Góis KA, Ribeiro RF Jr, et al. The prevalence of severe maternal morbidity and near miss and associated factors in Sergipe, Northeast Brazil. BMC Pregnancy Childbirth 2014;14:25

11. Beksaç S, Adamova G, Antolic ZN, Crnogorac S, Gliozheni O, Koç A, et al. South East Europe and Maternal Mortality. Gynecol Obstet Reprod Med 2008;14(3):159-62. 